\title{
Doživljanje nasilja v mladostništvu: vloga odnosov z vrstniki, odnosov z učitelji ter čustvenih in socialnih kompetenc
}

\author{
Tina Pivec in Ana Kozina
}

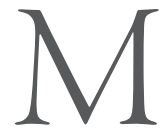

edvrstniška viktimizacija (doživljanje medvrstniškega nasilja) ostaja eno izmed najbolj raziskovanih področij in hkrati tudi ena izmed najbolj perečih težav v šolah (Košir, Pivec, Klasinc, Špes in Horvat, 20I8). Izpostavljenost nasilju ima za učence tako kratkoročne kot tudi dolgoročne posledice. Te so npr. anksioznost, depresivnost, nižja samopodoba, osamljenost in zmanjšana učna uspešnost (Hawker in Boulton, 2000; Isaacs, Hodges in Salmivalli, 2008), zato je poznavanje dejavnikov, ki nanjo vplivajo, ključno za vzpostavljanje učinkovitih intervencij za zmanjšanje viktimizacije $\mathrm{v}$ šolah. $V$ raziskavi sva se osredinili na dejavnike na ravni odnosov $\mathrm{z}$ vrstniki, na ravni odnosov $\mathrm{z}$ učitelji in na ravni posameznika (čustvene in socialne kompetence), ki sva jih na podlagi predhodnih raziskav povezali z doživljanjem nasilja v šoli.

Doživljanje medvrstniškega nasilja je še posebej težavno v času mladostništva, saj je to obdobje, ko postanejo odnosi z vrstniki razvojnopsihološko pomembni. $\mathrm{V}$ tem času učencem sovrstniki predstavljajo čustveno in socialno oporo, $\mathrm{z}$ njimi preživijo veliko časa tako $\mathrm{v}$ šoli kot izven nje, $v$ istem obdobju postane zelo pomemben tudi socialni status učenca (LaFontana in Cillessen, 20ı0). Posledično tako pozitivni vrstniški odnosi predstavljajo varovalni dejavnik v kontekstu viktimizacije. Mednje lahko štejemo prijateljstvo, socialno oporo vrstnikov in socialno sprejetost (Card in Hodges, 2008). V šolskem kontekstu pomembno vlogo igrajo tudi odnosi med učenci in učitelji, za katere je bilo ugotovljeno, da so pozitivni odnosi med učenci in učitelji varovalni dejavnik doživljanja nasilja, negativni odnosi z učitelji pa dejavnik tveganja za razvoj viktimizacije (Elledge, Elledge, Newgent in Cavell, 2016; Troop-Gordon 
in Kopp, 20II). Nenazadnje so pri viktimizaciji zelo pomembne tudi lastnosti na ravni posameznika, kot so čustvene in socialne kompetence. Učenci, ki posedujejo čustvene in socialne kompetence, so v manjši meri žrtve medvrstniškega nasilja, saj ne predstavljajo t. i. »lahkih tarč«, ki jih nasilneži navadno izbirajo med sramežljivimi in negotovimi učenci (Olweus, 1997), prav tako se zaradi virov, ki jih te kompetence zanje predstavljajo, na morebitno nasilje odzovejo na primeren način, kar prav tako zmanjša verjetnost, da postanejo žrtve nasilja (Lenzi et al., 2015).

\section{Viktimizacija (doživljanje nasilja)}

Viktimizacijo (t. i. doživljanje nasilja) je mogoče opredeliti kot izpostavljenost učenca nasilju, ki se s strani enega vrstnika ali skupine vrstnikov ponavlja dalj časa (Olweus, 1997). Medvrstniško nasilje in viktimizacija sta povezana, vendar ne identična konstrukta. Na podlagi številnih definicij medvrstniškega nasilja in viktimizacije lahko ugotovimo, da je za izvajanje in tudi doživljanje nasilja značilno naslednje (Salmivalli in Peets, 2009): I) namen nasilja je škodovati, 2) izvajanje nasilja se ponavlja dalj časa in 3) med nasilnežem in žrtvijo obstaja razlika v moči (žrtev se s težavo brani pred nasilnežem). Slednje ni nujni pogoj pri viktimizaciji, saj se doživljanje nasilja lahko zgodi tudi pri posameznikih, ki so drug drugemu enakovredni, vendar je ravno neravnotežje moči pomemben dejavnik pri pojavu prilagoditvenih težav učencev (Malecki et al., 2015).

Učenci, ki doživljajo nasilje, sicer predstavljajo heterogeno skupino, vendar je mogoče izluščiti naslednje skupne značilnosti: višja podredljivost, negotovost vase, nesprejetost s strani vrstnikov (Card in Hodges, 2008) ter širša kategorija težav na področju ponotranjenja. Dejavniki tveganja za razvoj viktimizacije so hkrati posledice doživljanja nasilja (Juvonen in Graham, 20I4), kar kaže, da se žrtve velikokrat vrtijo v začaranem krogu, saj doživljajo nasilje zaradi nekaterih svojih psihosocialnih težav (npr. anksioznost, slabše socialne spretnosti), posledično pa doživljanje nasilja vpliva na nastanek teh težav. V skupini viktimiziranih posameznikov so prav tako učenci, ki hkrati doživljajo nasilje in ga sami tudi izvajajo (t. i. nasilneži-žrtve); ti predstavljajo najbolj ranljivo skupino med vsemi učenci, ki so vključeni v pojav medvrstniškega nasilja in viktimizacije (Yang, Li in Salmivalli, 2016).

\section{Dejavniki na ravni odnosov z vrstniki}

Vrstniki lahko na več načinov vplivajo na pojav viktimizacije, saj zgolj to, da imajo učenci enega prijatelja, zmanjša tveganje za pojav viktimizacije (Hodges in Perry, 1999). Pri tem so pomembne tudi lastnosti prijatelja in kakovost prijateljstva (Bollmer, Milich, Harris in Maras, 2005; Sainio, 
Veenstra, Huitsing in Salmivalli, 20II), saj imeti prijatelja, ki je prav tako deležen nasilja, predstavlja dejavnik tveganja za nastanek viktimizacije (Sentse, Dijkstra, Salmivalli in Cillessen, 2013). Pri viktimizaciji še posebej veliko vlogo igrajo tudi preostali vrstniki, in sicer $\mathrm{z}$ vidika socialne opore, ki jo nudijo učencu (Du, DeGuisto, Albright in Alrehaili, 2018), prav tako pa so preostali vrstniki, ki v nasilje niso vključeni, opazovalci nasilja, ki lahko bodisi spodbujajo nasilneža bodisi branijo žrtev in s tem pomembno vplivajo na nadaljnjo pojavnost viktimizacije (Caravita, Di Blasio in Salmivalli, 2009). Na splošno je torej mogoče trditi, da pozitivna plat odnosov z vrstniki učence na nek način ščiti pred pojavom viktimizacije. Pri tem pomembno vlogo igra prosocialno vedenje, ki ga je mogoče opredeliti kot skupek prostovoljnih dejanj, ki jih posameznik stori zato, da pomaga drugim; med taka dejanja sodita altruistična pomoč in sodelovanje (Eisenberg, Fabes in Spinrad, 2006). Učenci, za katere je značilno prosocialno vedenje, imajo več možnosti za pozitivne odnose z vrstniki, zaradi česar prosocialno vedenje predstavlja varovalni dejavnik viktimizacije (Griese, Buhs in Lester, 2016), a vendar je lahko pri učencih potreba po pripadnosti dovolj močna, da ne glede na doživljanje nasilja delujejo prosocialno (Griese in Buhs, 20I4). Te povezave odpirajo nova raziskovalna vprašanja o smeri teh povezav.

Na drugi strani negativna plat odnosov, težavno vedenje učencev, predstavlja dejavnik tveganja. Težavno vedenje zajema široko paleto vedenj, ki vključujejo agresivnost, delikventnost in druga antisocialna vedenja (Racz in McMahon, 2orI). Predhodne raziskave so pokazale, da lahko težavno vedenje napoveduje verjetnost, da bo učenec postal žrtev nasilnega vedenja (Marengo et al., 2018). Pri tem je treba opozoriti, da je vzdolžna raziskava, ki so jo izvedli Schwartz in sodelavci (Schwartz, McFadyen-Ketchum, Dodge, Pettit in Bates, 1998), pokazala, da je doživljanje viktimizacije po poročanju staršev in učiteljev dve leti kasneje povezano $s$ težavnim vedenjem. Navedeno kaže na povezanost viktimizacije in težavnega vedenja, pri čemer je mogoče zaključiti, da težavno vedenje predstavlja dejavnik tveganja za razvoj viktimizacije.

\section{Dejavniki na ravni odnosov z učitelji}

Učitelji imajo ključno vlogo pri ustvarjanju podpornega in spodbudnega šolskega okolja z vzpostavljanjem dobrih odnosov z učenci, vodenjem razreda in s predstavljanjem pozitivnega vzgleda za učence (Di Stasio, Savage in Burgos, 2016). Odnosi med učenci in učitelji vplivajo na razvoj socialnih spretnosti učencev, učno zavzetost, pozitiven odnos učencev do šole (Hamre in Pianta, 2005) in so povezani z višjo sprejetostjo s strani vrstnikov ter z nižjo stopnjo pozunanjenih težav učencev (Troop-Gordon 
in Kopp, 20II). Zraven pomembnosti pozitivnih odnosov med učitelji in učenci (Raskauskas, Rubiano, Offen in Wayland, 2015) so učitelji tudi pomemben vir informacij. Učitelji so tisti odrasli, ki imajo največ informacij o medvrstniškem nasilju in viktimizaciji v šoli (Waasdorp, Pas, O'Brennan in Bradshaw, 20II) ter lahko vplivajo na pogostost $\mathrm{z}$ izvajanjem učinkovitega razrednega managementa in preko lastnih prepričanj o nasilju (Troop-Gordon in Ladd, 2015). Pri tem je treba opozoriti na ugotovitve, da s strani učencev zaznani odnosi z učitelji niso povezani s poročanjem o viktimizaciji (Wang, Leary, Taylor in Derosier, 2016). Vzdolžna raziskava viktimizacije (Troop-Gordon in Kopp, 20II) je pokazala, da pozitivni odnosi med učenci in učitelji ne varujejo učencev pred pojavom viktimizacije. Hkrati raziskovalni izsledki kažejo na pomembno vlogo negativnih odnosov med učenci in učitelji, ki so povezani z višjo stopnjo medvrstniške viktimizacije v šolskem okolju (Lucas-Molina, Williamson, Pulido in Perez-Albeniz, 2015). Če učenci poročajo o slabšem odnosu z učitelji, to vpliva na to, da so bolj ranljivi za doživljanje psihičnega distresa ob doživljanju viktimizacije (Sulkowski in Simmons, 2017). Pri negativnih odnosih med učenci in učitelji je pomemben tudi vpliv na negativno razredno klimo, ki posredno vpliva na pojav viktimizacije $\mathrm{v}$ razredu (Thornberg, Wänström in Pozzoli, 2017).

\section{Čustvene in socialne kompetence}

$\mathrm{Na}$ odnose tako med vrstniki kot z učitelji pomembno vplivajo čustvene in socialne kompetence. Med čustvene in socialne kompetence uvrščamo samozavedanje, samouravnavanje, socialno zavedanje, odgovorno sprejemanje odločitev in uspešno upravljanje z odnosi (Durlak, Dymnicki, Taylor, Weissberg in Schellinger, 2orI). Samozavedanje sestavljajo prepoznavanje lastnih čustev in občutij, realna ocena lastnih sposobnosti in spretnosti ter samopodoba. Socialno zavedanje je mogoče opredeliti kot zaznavo čustev in občutkov drugih ter kot pozitiven odnos do drugih in aktivno vključenost v različne skupine. Samouravnavanje je nadzorovanje lastnih čustev, sposobnost odložitve nagrade zaradi sledenja ciljem in vztrajnost kljub morebitnim neuspehom. Uspešno upravljanje z odnosi je učinkovit nadzor čustev in odnosov, vzpostavljanje in ohranjanje dobrih medsebojnih odnosov. Odgovorno sprejemanje odločitev temelji na upoštevanju vseh pomembnih dejavnikov in poznavanju najverjetnejših posledic različnih dejanj, spoštovanju drugih in prevzemanju osebne odgovornosti za lastne odločitve (Weissberg, Durlak, Domitrovich in Gullotta, 2015).

Pri medvrstniškem nasilju in viktimizaciji je ključno razumevanje vpliva teh kompetenc na pojavnost in pogostost obeh pojavov (Hymel in Swearer, 2015). Znotraj samozavedanja je v kontekstu viktimizacije 
najbolj raziskana vloga samopodobe in $\mathrm{v}$ zadnjem obdobju tudi čuječnosti. Žrtve poročajo o nižji stopnji samopodobe kot učenci, ki niso vključeni v medvrstniško nasilje (Fanti in Henrich, 2015; O'Moore in Kirkham, 2002), prav tako pa je socialna samopodoba negativen napovednik različnih oblik viktimizacije (Košir et al., 2018). Nedavno je bilo ugotovljeno, da je pomemben vidik samozavedanja - čuječnost, ki jo je mogoče opredeliti kot neobsojajoče in sprejemajoče zavedanje življenjskih izkušenj (Brown in Ryan, 2003) -, negativno povezan z izkušnjo viktimizacije (Riggs in Brown, 2017); kljub temu ostaja ta vidik samozavedanja pretežno neraziskan. Za samouravnavanje je bilo ugotovljeno, da se negativno povezuje z viktimizacijo (Jenkins, Demaray, Fredrick in Summers, 2016), pri čemer je pomemben nadzor čustev, predvsem jeze, saj nižja stopnja nadzora jeze in odziv na nasilno vedenje vodita do povišanega tveganja za nadaljnje doživljanje nasilja (Spence, de Young, Toon in Bond, 2009). Nadalje je zaradi socialnega konteksta viktimizacije še posebej pomemben vidik socialnega zavedanja, v sklopu katerega so bile raziskane predvsem razredne norme in empatija. Veliko raziskovalcev je preučevalo povezavo med empatijo in viktimizacijo, a rezultati niso enoznačni, saj je metaanaliza raziskav empatije in viktimizacije pokazala, da ni povezave med empatijo in viktimizacijo (Zych, Ttofi in Farrington, 2019), medtem ko druge raziskave poročajo o negativni povezanosti (Jenkins et al., 2016). Empatijo je mogoče deliti na kognitivno in afektivno empatijo, pri čemer kognitivna komponenta empatije odraža sposobnost posameznika, da razume perspektivo drugih, afektivna komponenta pa se nanaša na doživljanje občutkov skrbi ali simpatije do drugih (Davis, 1996). V povezavi z viktimizacijo in obema vidikoma empatije je bilo ugotovljeno naslednje: van Noordnova je skupaj s sodelavci (van Noorden, Haselager, Cillessen in Bukowski, 2015) na podlagi metaanalize raziskav ugotovila, da je viktimizacija negativno povezana s kognitivno, ne pa tudi z afektivno empatijo. Za afektivno empatijo je bilo ugotovljeno tudi, da se telesna in besedna viktimizacija $\mathrm{z}$ njo pozitivno povezujeta (Kokkinos in Kipritsi, 20I2).

V pričujoči raziskavi sva želeli zapolniti vrzeli pri prepoznavanju posameznih varovalnih dejavnikov in dejavnikov tveganja pri razvoju viktimizacije $v$ času mladostništva. Zaradi vzročno-posledičnega odnosa med viktimizacijo in ponotranjenimi težavami ter zaradi pojava negativnih posledic kasneje $\mathrm{v}$ življenju je nujno prepoznavanje raznolikih dejavnikov, ki vplivajo na pojav doživljanja nasilja v šoli z namenom odzivanja na nasilje in njegovega preprečevanja ter ponujanja psihosocialne pomoči njegovim žrtvam. Zaradi pomanjkanja raziskav na področju čustvenih in socialnih kompetenc (empatija, samozavedanje in 
samopodoba), vrstniških odnosov (pozitivni odnosi z vrstniki, težavno vedenje in prosocialno vedenje) in (pozitivnih ter negativnih) odnosov učencev $\mathrm{z}$ učitelji $\mathrm{v}$ kontekstu viktimizacije $\mathrm{v}$ slovenskem šolskem prostoru je bil namen raziskave preveriti vlogo omenjenih dejavnikov in predlagati smernice za preprečevanje in odzivanje na viktimizacijo med učenci za pedagoške delavce. Zaradi neraziskane mediatorske vloge negativnih odnosov med učenci in učitelji v kontekstu psihosocialnih značilnosti učencev in viktimizacije $\mathrm{v}$ slovenskem šolskem prostoru, ki lahko še dodatno okrepijo doživljanje viktimizacije za učence (Elledge et al., 2016; Huang, Lewis, Cohen, Prewett in Herman, 2018), sva želeli preveriti vpliv odnosov med učenci in učitelji na odnos med psihosocialnimi značilnostmi učencev in viktimizacijo. Slednje z namenom, da bi predlagali smernice na sistemski ravni, na primer vključevanje dodatnih vsebin $\mathrm{v}$ izobraževanje bodočih učiteljev in pedagoških delavcev $\mathrm{v}$ slovenskem šolskem prostoru.

Na podlagi teoretičnih izhodišč sva oblikovali naslednji raziskovalni vprašanji:

I. V kolikšni meri posamezni psihosocialni dejavniki napovedujejo viktimizacijo pri učencih? Ožje se bova osredinili na dejavnike na ravni vrstnikov (pozitivni odnosi z vrstniki, težavno vedenje in prosocialno vedenje), na dejavnike na ravni odnosov z učitelji (pozitivni in negativni odnosi z učitelji) in na dejavnike na ravni posameznika (čustvene in socialne kompetence: samopodoba, samozavedanje in empatija). Pri tem na podlagi teoretičnih izhodišč predpostavljava, da bodo pozitivni odnosi z vrstniki in prosocialno vedenje statistično značilen negativni napovednik viktimizacije, težavno vedenje pa pozitiven napovednik viktimizacije. Pri odnosih z učitelji predpostavljava, da bodo pozitivni odnosi med učenci in učitelji pozitiven napovednik viktimizacije, negativni odnosi pa negativen napovednik viktimizacije. Pri čustvenih in socialnih kompetencah v povezavi $\mathrm{z}$ viktimizacijo pa, da bosta samopodoba in samozavedanje negativna napovednika viktimizacije, empatija pa ne bo statistično značilen napovednik viktimizacije.

2. Ali negativni odnosi med učenci in učitelji mediirajo odnos med preverjanimi psihosocialnimi značilnostmi (pozitivni odnosi z vrstniki, težavno vedenje, prosocialno vedenje, samopodoba, empatija, samozavedanje) in viktimizacijo? Negativni odnosi med učenci in učitelji namreč lahko dodatno prispevajo $\mathrm{k}$ pojavu viktimizacije v razredu. Na podlagi teoretičnih izhodišč tako predpostavljava, da 
bodo negativni odnosi med učenci in učitelji mediatorji odnosa med navedenimi značilnostmi učencev in viktimizacijo.

\section{Metoda}

\section{Udeleženci}

V pilotni raziskavi projekta Roka v roki: Socialne in čustvene spretnosti za nediskriminatorno in vključujočo skupnost (Kozina et al., 2017), katerega namen je krepitev čustvenih, socialnih in medkulturnih kompetenc med učenci in učitelji, je sodelovalo 123 učencev, starih med 13 in Is let $(\mathrm{M}=13,20, \mathrm{SD}=0,42)$. Vsi učenci, ki so sodelovali v raziskavi, so obiskovali 8. razred osnovne šole. Podatki so bili zbrani na šestih osnovnih šolah v Sloveniji.

\section{Pripomočki}

Viktimizacija. Za merjenje doživljanja nasilja je bil uporabljen Olweusov vprašalnik nasilnež/žrtev (Olweus Bully/Victim Questionnaire, OBWQ; Olweus, 1996), ki je bil za namen raziskave prilagojen tako, da so udeleženci odgovarjali zgolj o nasilju v razredu. Vprašalnik je sestavljen iz dveh delov, en del meri izvajanje nasilja, drugi del pa doživljanje nasilja, zato je bil za merjenje doživljanja nasilja uporabljen zgolj drugi del vprašalnika. Lestvica viktimizacije vsebuje 22 postavk. Udeleženci so na 4 -stopenjski lestvici označili, v kolikšni meri so v zadnjih štirih mesecih doživljali posamezno obliko nasilja ( - nikoli ali skoraj nikoli, 2 - enkrat na mesec, 3 - enkrat na teden, 4 - vsak dan ali skoraj vsak dan). Primer postavke: »Sošolci/-ke so se mi smejali/-e in s prstom kazali/-e name.« Na našem vzorcu se je pokazala ustrezna zanesljivost (Cronbachov $\alpha=0,92$ ) mere viktimizacije, o podobni zanesljivosti poročajo tudi drugi avtorji (Solberg in Olweus, 2003).

Težavno vedenje. Za merjenje težavnega vedenja je bila uporabljena podlestvica Težavno vedenje iz Vprašalnika prednosti in slabosti (Strenghts and Difficulties Questionnaire, SDQ; Goodman, 1997). Udeleženci so na 4-stopenjski lestvici ( 1 - močno se ne strinjam, 4 močno se strinjam) označili, katere postavke veljajo za njih. Podlestvica Težavno vedenje zajema 6 postavk, primer postavke: »Pogosto se tepem z drugimi otroki.« Na našem vzorcu se je pokazala dokaj nizka zanesljivost mere težavnega vedenja (Cronbachov $\alpha=0,53)$, kar lahko pripišemo temu, da se omenjeni vprašalnik uporablja zgolj kot presejalni test v kliničnem okolju, prav tako pa je bil prvotno namenjen za uporabo staršev in učiteljev. Zanesljivost uporabljene podlestvice je bila preverjana tudi v 
prejšnjih raziskavah, kjer so prav tako poročali o nižji zanesljivosti (npr. Goodman, 200I).

Pozitivni odnosi $z$ vrstniki. $\mathrm{Za}$ merjenje spremenljivke odnosi z vrstniki je bila uporabljena podlestvica Težave v odnosih z vrstniki iz Vprašalnika prednosti in slabosti (Strenghts and Difficulties Questionnaire, SDQ; Goodman, 1997), kjer so udeleženci na 4-stopenjski lestvici ( - močno se ne strinjam, 4 - močno se strinjam) označili, katere postavke veljajo za njih. Podlestvica Težave v odnosih z vrstniki zajema 5 postavk, primer postavke je: $\gg \mathrm{Na}$ splošno sem med vrstniki priljubljen/-a.« Pri tem sva odgovore kodirali tako, da merijo pozitivne odnose z vrstniki. Na našem vzorcu se je pokazala nizka zanesljivost (Cronbachov $\alpha=0,53$ ), kar lahko ponovno pojasnimo s tem, da je uporabljeni vprašalnik namenjen zaznavanju vedenjskih težav otrok in mladostnikov v kliničnem okolju. Pri preverjanju zanesljivosti v predhodnih raziskavah je bilo prav tako ugotovljeno, da je zanesljivost nižja (Cronbachov $\alpha=0,41$; Goodman, 200I).

Prosocialno vedenje. Prosocialno vedenje sva merili $\mathrm{z}$ uporabo podlestvice Prosocialno vedenje iz Vprašalnika prednosti in slabosti (Strenghts and Difficulties Questionnaire, SDQ; Goodman, 1997). Podlestvica Prosocialno vedenje zajema 6 postavk, na katere so se udeleženci na 4-stopenjski lestvici ( $\mathrm{I}$ - nikoli, 4 - pogosto) odzvali, kako trditve veljajo zanje. Primer postavke: »Poskušam biti prijazen/-na do drugih.« Na vzorcu se je pokazala ustrezna zanesljivost podlestvice prosocialnega vedenja (Cronbachov $\alpha=0,82$ ), ki je celo višja kot v predhodnih raziskavah, saj je Goodman (200I) pri preverjanju koeficienta zanesljivosti na velikem vzorcu mladostnikov ugotovil slabšo zanesljivost podlestvice (Cronbachov $\alpha=0,66$ ).

Pozitivni odnosi z učitelji. Za preverjanje zaznanega pozitivnega odnosa z učitelji s strani učencev je bila uporabljena prilagojena verzija vprašalnika Učitelj kot socialni kontekst (Teacher as Social Context, TASC; Belmont, Skinner, Wellbron in Connell, 1992), saj so bile uporabljene zgolj postavke, ki merijo pozitivno plat odnosa med učenci in učitelji. Udeleženci so na 4-stopenjski lestvici ( $\mathrm{I}$ - za nobenega ali skoraj nobenega, 2 - za nekatere, 3 - za večino, 4 - za vse ali skoraj vse) označili, za koliko njihovih učiteljev v obdobju zadnjih štirih mesecev veljajo trditve. Lestvica je zajemala 9 postavk, primer postavke: »Učitelji/-ce mi posvetijo svoj čas.« Zanesljivost uporabljenega vprašalnika je bila ustrezna, saj je Cronbachov $\alpha$ znašal o,9I.

Negativni odnosi $z$ ućitelji. Za merjenje zaznanega negativnega odnosa med učenci in učitelji s strani učencev je bil uporabljen prilagojeni vprašalnik (Dodano je bilo vprašanje: $\mathrm{V}$ zadnjih 4 mesecih 
so učitelji/-ice vpili/-e name.) učiteljeve pravičnosti, ki je bil uporabljen znotraj raziskave PISA (OECD, 2017). Udeleženci so na 4-stopenjski lestvici ( 1 - za nobenega ali skoraj nobenega, 2 - za nekatere, 3 - za večino, $4-$ za vse ali skoraj vse) označili, za koliko njihovih učiteljev $\mathrm{v}$ obdobju zadnjih štirih mesecev veljajo trditve. Primer postavke: $\gg \mathrm{V}$ zadnjih 4 mesecih so me učitelji/-ice užalili/-e pred drugimi.« Lestvica zajema 6 postavk, zanesljivost lestvice je ustrezna (Cronbachov $\alpha=0,8 \mathrm{I}$ ).

Samopodoba. Za merjenje samopodobe udeležencev je bil uporabljena podlestvica Splošna samopodoba iz Vprašalnika opisovanja samega sebe (Self-Description Questionnaire II, SDQ II; Marsh, 1992). Lestvica vsebuje ro postavk, pri čemer so udeleženci na 4-stopenjski lestvici ( $\mathrm{I}$ - sploh se ne strinjam, 4 - popolnoma se strinjam) označili, v kolikšni meri posamezna postavka velja zanje. Primer postavke: »Dobro opravim večino stvari, ki se jih lotim.« Zanesljivost je bila zadovoljiva, saj je Cronbachov $\alpha$ znašal 0,74 , nekoliko višja zanesljivost se je pokazala v prejšnjih raziskavah ( $\alpha=0,87$; Guérin, Marsh in Famose, 2003).

Empatija. Empatijo sva merili $\mathrm{z}$ Vprašalnikom empatije (Interpersonal Reactivity Index, IRI; Davis, 1980), ki je najpogostejša mera empatije. Vprašalnik sestavljajo 4 lestvice (Lestvica zavzemanja perspektive, Lestvica fantazije, Lestvica empatične skrbi, Lestvica osebne prizadetosti) in 28 postavk na 5 -stopenjski Likertovi lestvici, ki segajo od I (to nikakor ne velja zame) do 5 (to zelo velja zame); vsaka od podlestvic je sestavljena iz sedmih različnih postavk. $\mathrm{V}$ analizah sva uporabili Lestvico empatične skrbi in Lestvico prevzemanja perspektive, saj sva želeli preveriti skupni vidik kognitivne empatije s preverjanjem prevzemanja perspektive in afektivne empatije s preverjanjem empatične skrbi (glej Davis, 1983). Lestvica zavzemanja perspektive preverja tendenco posameznika $\mathrm{k}$ spontanem prevzemanju psihološkega stališča drugih ljudi (Primer postavke: $\gg V$ časih težko vidim stvari z vidika druge osebe.«). Lestvica empatične skrbi ocenjuje na druge usmerjene občutke sočutja in skrb za druge (Primer postavke: »Pogosto sočustvujem z ljudmi, ki so manj srečni od mene.«). Vrednosti na obeh lestvicah so bile v skladu z navodili avtorjev seštete. Podlestvici imata ustrezno konstruktno veljavnost, dobro notranjo zanesljivost $(\alpha>0,70)$ in test-retest zanesljivost $(\alpha>0,60)$ (npr. Bernstein in Davis, 1982). Na uporabljenem vzorcu se je prav tako pokazala ustrezna zanesljivost vprašalnika (Cronbachov $\alpha=0,82$ ).

Samozavedanje. Za merjenje samozavedanja je bila uporabljena Kentuckyjeva lestvica čuječnosti (Kentucky Mindfulness Scale, KIMS; Baer, Smith in Allen, 2004). Vprašalnik sestoji iz štirih podlestvic (opazovanje, opisovanje, zavestno delovanje, sprejemanje brez obsojanja), 
vendar sva za analizo uporabili le podlestvici opazovanje in opisovanje, saj sva želeli preveriti zgolj opazovanje in opisovanje telesnih občutij, zaznav, misli in čustev učencev. Podlestvica opazovanje obsega 12 postavk (Primer postavke: $\gg$ Namenoma posvečam pozornost svojim občutkom.«), podlestvica opisovanje pa 8 postavk (Primer postavke: $\gg Z$ lahkoto ubesedim svoja prepričanja, mnenja in pričakovanja.«). Po navodilih avtorjev vprašalnika sva vrednosti na obeh podlestvicah sešteli. Zanesljivost uporabljenih lestvic, s katerima sva merili samozavedanje, je bila dobra (Cronbachov $\alpha=0,86$ ), v prejšnjih raziskavah so prav tako poročali o ustrezni zanesljivosti posameznih lestvic (npr. Baer et al., 2004: opazovanje: ০,9I; opisovanje: ०,84).

\section{Postopek in statistična obdelava podatkov}

Podatki so bili po predhodno pridobljenem prostovoljnem soglasju staršev oz. skrbnikov zbrani v osmih razredih na osnovnih šolah v Sloveniji. Reševanje vprašalnikov je bilo časovno neomejeno ter je potekalo med eno in dvema šolskima urama. Zaradi preverjanja merskih pripomočkov je bil prvotni vzorec $(\mathrm{N}=233)$ razdeljen na dva dela: $\mathrm{A}$ in $\mathrm{B}$, od katerih je vsak del vzorca reševal druge vprašalnike. Za namene naše raziskave sva uporabili vzorec A, ki je obsegal I27 udeležencev, vendar so bili naknadno izključeni tisti štirje udeleženci, ki so imeli na celotnem vprašalniku izpolnjenih manj kot $90 \%$ vprašanj. Na končnem vzorcu je bil delež manjkajočih vrednosti majhen, obsegal je manj kot $4 \%$ za posamezno spremenljivko. Manjkajoče vrednosti sva zaradi naključno manjkajočih podatkov nadomestili s pomočjo EM algoritma, ki vrednosti ne nadomesti neposredno, ampak izračuna ocene za želene parametre po metodi največjega verjetja. Za preverjanje napovedne vrednosti posameznih spremenljivk je bila uporabljena hierarhična multipla regresijska analiza, za preverjanje mediatorske vloge pozitivnih in negativnih odnosov med učenci in učitelji sva $\mathrm{v}$ programu IBM SPSS Statistics 25 uporabili dodatek Process Macro.

\section{Rezultati}

Najprej sva preverili porazdelitev vključenih spremenljivk in izračunali opisne statistike ter korelacije med posameznimi spremenljivkami. Nadalje sva preverjali napovednike viktimizacije, pri čemer navajava rezultate hierarhične multiple regresijske analize. $S$ pomočjo mediacijske analize sva preverjali vpliv pozitivnih in negativnih odnosov med učenci in učitelji na odnos med preverjanimi psihosocialnimi značilnostmi in viktimizacijo, kar je razvidno iz slikovnega prikaza. Pri preverjanju normalnosti porazdelitve sva ugotovili, da samo spremenljivki viktimizacija in negativni odnosi z učitelji nista normalno porazdeljeni, zato sva, da bi 
dosegli normalno porazdelitev vseh spremenljivk, omenjeni spremenljivki logaritmirali.

Pregled Pearsonovih korelacij (Tabela ı) kaže, da je viktimizacija statistično značilno negativno povezana s pozitivnimi odnosi z vrstniki in prosocialnim vedenjem ter statistično značilno pozitivno povezana $s$ težavnim vedenjem in negativnimi odnosi z učitelji. Statistično značilno med seboj korelirajo negativni odnosi z učitelji in težavno vedenje, medtem ko med pozitivnimi odnosi z vrstniki in pozitivnimi odnosi z učitelji ni statistično značilne povezave. Pozitivni odnosi z vrstniki se statistično značilno pozitivno povezujejo zgolj s samopodobo, medtem ko se težavno vedenje statistično značilno negativno povezuje s prosocialnim vedenjem, pozitivnimi odnosi z učitelji, samopodobo in empatijo. Pozitivni odnosi $z$ učitelji so statistično značilno pozitivno povezani s prosocialnim vedenjem, samopodobo in empatijo. Vse spremenljivke, s katerimi sva merili konstrukt čustvenih in socialnih kompetenc razen samozavedanja, so negativno statistično značilno povezane z negativnimi odnosi z učitelji. Samopodoba in empatija med seboj ne korelirata, medtem ko obstaja statistično značilna pozitivna povezava med samozavedanjem in empatijo.

Tabela r: Deskriptivna statistika in korelacije.

\begin{tabular}{|c|c|c|c|c|c|c|c|c|c|c|}
\hline & M & $\mathrm{SD}$ & I. & 2. & 3. & 4. & 5. & 6. & 7. & 8. \\
\hline I. Viktimizacija & 0,26 & 0,26 & & & & & & & & \\
\hline $\begin{array}{l}\text { 2. Pozitivni } \\
\text { odnosi z vrstniki }\end{array}$ & 3,12 & 0,48 & $-0,24^{* *}$ & & & & & & & \\
\hline $\begin{array}{l}\text { 3. Težavno } \\
\text { vedenje }\end{array}$ & 1,92 & 0,42 & $0,35^{* *}$ & $-0,03$ & & & & & & \\
\hline $\begin{array}{l}\text { 4. Prosocialno } \\
\text { vedenje }\end{array}$ & 3,29 & 0,59 & $-0,25^{* *}$ & 0,09 & $-0,50^{* *}$ & & & & & \\
\hline $\begin{array}{l}\text { 5. Pozitivni } \\
\text { odnosi z učitelji }\end{array}$ & 2,48 & $0,7 \mathrm{I}$ & $-0,06$ & 0,08 & $-0,33^{* *}$ & $0,47^{* *}$ & & & & \\
\hline $\begin{array}{l}\text { 6. Negativni } \\
\text { odnosi z učitelji }\end{array}$ & $0,4 \mathrm{I}$ & 0,29 & $0,43^{* *}$ & $-0,03$ & $0,54^{* *}$ & $-0,39^{* *}$ & $-0,36^{* *}$ & & & \\
\hline 7. Samopodoba & $3,5 \mathrm{I}$ & 0,39 & $-0,17$ & $0,32^{* *}$ & $-0,37^{* *}$ & $0,17^{* *}$ & $0,34^{* *}$ & $-0,29^{* *}$ & & \\
\hline 8. Empatija & 33,32 & 7,90 & 0,03 & $\mathrm{O}, \mathrm{OI}$ & $-0,36^{* *}$ & $0,60^{* *}$ & $0,4 \mathrm{I}^{* *}$ & $-0,25^{*}$ & 0,09 & \\
\hline $\begin{array}{l}\text { 9. Samo- } \\
\text { zavedanje }\end{array}$ & 28,62 & 5,94 & 0,07 & 0,04 & $-0,15$ & 0,16 & $0,24^{* *}$ & 0,06 & 0,05 & $0,4 \mathrm{I}^{* *}$ \\
\hline
\end{tabular}

Opombe: ${ }^{*} p<0,05,{ }^{* *} p<0,00 I$.

\section{Napovedniki viktimizacije}

Za določanje napovedne vrednosti medvrstniških odnosov, odnosov z učitelji ter čustvenih in socialnih kompetenc sva uporabili hierarhično regresijsko analizo z metodo vključitve (angl. enter). Preliminarne analize so 
Tabela 2: Hierarhična multipla regresijska analiza za spremenljivke, ki napovedujejo viktimizacijo.

\begin{tabular}{|c|c|c|c|c|c|c|}
\hline & \multicolumn{6}{|c|}{ Viktimizacija } \\
\hline & \multicolumn{2}{|c|}{ Model I } & \multicolumn{2}{|c|}{ Model 2} & \multicolumn{2}{|c|}{ Model $_{3}$} \\
\hline & $\mathrm{B}$ & $\beta$ & $\mathrm{B}$ & $\beta$ & $\mathrm{B}$ & $\beta$ \\
\hline \multicolumn{7}{|l|}{ Korak I: } \\
\hline $\begin{array}{l}\text { Pozitivni odnosi z } \\
\text { vrstniki }\end{array}$ & $-0,12$ & $-0,22^{* *}$ & $-0,13$ & $-0,23^{* *}$ & $-0,13$ & $-0,24^{* *}$ \\
\hline Težavno vedenje & 0,19 & $0,30^{* *}$ & 0,10 & 0,15 & 0,12 & 0,18 \\
\hline Prosocialno vedenje & $-0,04$ & $-0,09$ & $-0,05$ & $-0,10$ & $-0,07$ & $-0,17$ \\
\hline $\mathrm{R}^{2}$ & & $\mathrm{O}, 18^{* * *}$ & & & & \\
\hline \multicolumn{7}{|l|}{ Korak 2: } \\
\hline $\begin{array}{l}\text { Pozitivni odnosi z } \\
\text { učitelji }\end{array}$ & & & 0,07 & $0,19^{*}$ & 0,05 & $\mathrm{O}, \mathrm{I} 4$ \\
\hline $\begin{array}{l}\text { Negativni odnosi z } \\
\text { učitelji }\end{array}$ & & & 0,34 & $0,37^{* * *}$ & 0,33 & $0,36^{* * *}$ \\
\hline$\Delta \mathrm{R}^{2}$ & & & & $\mathrm{O}, \mathrm{IO}^{* * *}$ & & \\
\hline \multicolumn{7}{|l|}{ Korak 3: } \\
\hline Samopodoba & & & & & 0,03 & 0,04 \\
\hline Empatija & & & & & O,OI & O,I 4 \\
\hline Samozavedanje & & & & & ०,०० & 0,07 \\
\hline$\Delta \mathrm{R}^{2}$ & & & & & & 0,02 \\
\hline $\mathrm{R}^{2}$ & \multicolumn{2}{|c|}{$0,18^{* * *}$} & \multicolumn{2}{|c|}{$0,28^{* * *}$} & \multicolumn{2}{|c|}{0,30} \\
\hline F za spremembo $\mathrm{R}^{2}$ & \multicolumn{2}{|c|}{$8,49^{* * *}$} & \multicolumn{2}{|c|}{$8,4 \mathrm{I}^{* * *}$} & \multicolumn{2}{|c|}{$\mathrm{I}, \mathrm{I} 4$} \\
\hline
\end{tabular}

Opombe: ${ }^{*} p<0,05,{ }^{* *} p<0,0 I,{ }^{* * *} p<0,00 I$.

pokazale, da so izpolnjene vse predpostavke za izvedbo hierarhične regresije. Na podlagi indikatorjev VIF (angl. variance inflation factor) je mogoče ugotoviti, da v naših podatkih ni težav z multikolinearnostjo (indikatorji VIF so med I in 2). Pri preverjanju obstoja vplivnih točk, ki bi lahko popačile regresijski model, sva ugotovili, da odstopanj ni mogoče zaznati (vrednosti Cookove razdalje so bile med o,o० in ०,07). Pri pregledu preostalih predpostavk sva ugotovili, da za izbrane modele bistveno ne kršiva predpostavk homoskedastičnosti, linearnosti in približno normalne porazdelitve rezidualov (standardizirani koeficienti so bili med $-2,46$ in 2,68).

$\mathrm{V}$ prvi korak sva vključili dejavnike na ravni odnosov z vrstniki (pozitivni odnosi z vrstniki, težavno vedenje in prosocialno vedenje) in $\mathrm{v}$ drugi korak odnose $\mathrm{z}$ učitelji (pozitivni odnosi z učitelji in negativni odnosi z učitelji). V zadnjem, tretjem koraku sva vključili mere čustvenih in socialnih kompetenc (samopodoba, empatija in samozavedanje) (Tabela 2). 
Rezultati so pokazali, da spremenljivke pozitivni odnosi z vrstniki, težavno vedenje in prosocialno vedenje v prvem koraku pojasnijo I8 \% viktimizacije. V tem koraku se je pokazalo, da sta spremenljivki pozitivni odnosi z vrstniki in težavno vedenje pomembna napovednika viktimizacije, kar pa ne velja za prosocialno vedenje. Pozitivni odnosi z vrstniki negativno napovedujejo viktimizacijo, težavno vedenje pa pozitivno; učenci, ki svoje odnose z vrstniki zaznavajo kot pozitivne, poročajo o nižji stopnji viktimizacije, medtem ko učenci, ki imajo vedenjske težave, poročajo o višji stopnji viktimizacije.

Vključitev odnosov z učitelji v model dodatno pojasni to \% viktimizacije. Pomemben napovednik viktimizacije predstavljajo tako pozitivni in negativni odnosi z učitelji. Pozitivni odnosi z učitelji so statistično značilen pozitiven napovednik viktimizacije, kar kaže na to, da s strani učencev zaznani pozitivni odnosi z učitelji vplivajo na povišanje viktimizacije, negativni odnosi z učitelji so prav tako pozitiven napovednik viktimizacije; slabše, kot so s strani učencev zaznani odnosi z učitelji, tem višja je poročana stopnja viktimizacije učencev. Ob upoštevanju odnosov z učitelji se je pokazalo, da težavno vedenje ni več pomemben napovednik viktimizacije.

$\mathrm{V}$ zadnjem koraku so bile vključene mere čustvenih in socialnih kompetenc, s katerimi je mogoče pojasniti $2 \%$ viktimizacije, vendar nobena od uporabljenih mer čustvenih in socialnih kompetenc (samopodoba, empatija, samozavedanje) ni pomemben napovednik viktimizacije. Ob vključitvi čustvenih in socialnih kompetenc v model se je pokazalo, da pozitivni odnosi z učitelji niso več napovednik viktimizacije.

Skupno model z vsemi vključenimi spremenljivkami pojasni $30 \%$ viktimizacije. Na podlagi rezultatov lahko zaključimo, da predstavljajo pozitivni odnosi z vrstniki varovalni dejavnik pred pojavom viktimizacije in da veliko vlogo pri pojavu viktimizacije igrajo zaznani negativni odnosi med učenci in učitelji, ki predstavljajo dejavnik tveganja.

\section{Mediatorski vpliv negativnih odnosov z učitelji}

Negativni odnosi med učenci in učitelji lahko še dodatno prispevajo $\mathrm{k}$ pojavu viktimizacije, zato sva se v luči tega odločili preveriti, kako ob vključitvi v model mediirajo odnos med preverjanimi psihosocialnimi značilnostmi učencev (pozitivni odnosi z vrstniki, težavno vedenje, samopodoba, empatija, samozavedanje in prosocialno vedenje) in viktimizacijo. 


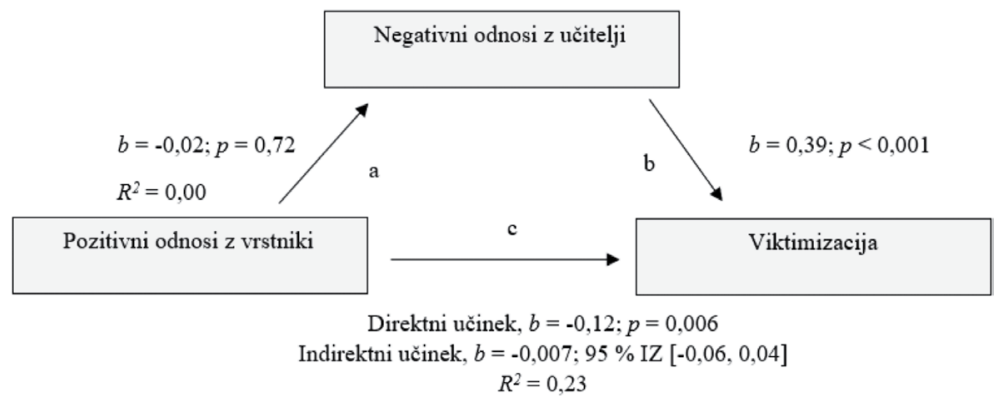

Slika I: Mediatorski odnos med pozitivnimi odnosi z vrstniki in viktimizacijo ter negativnimi odnosi z učitelji kot mediatorjem odnosa.

Pri preverjanju mediatorske vloge negativnih odnosov z učitelji sva najprej preverili njihov vpliv na odnos med pozitivnimi odnosi z vrstniki in viktimizacijo (Slika I). Rezultati kažejo, da pozitivni odnosi z vrstniki ne napovedujejo negativnih odnosov z učitelji (pot a), negativni odnosi z učitelji pa so pozitiven napovednik viktimizacije. Pozitivni odnosi z vrstniki pa kljub vključitvi negativnih odnosov z učitelji v model ostajajo negativen napovednik viktimizacije. Do mediatorskega učinka negativnih odnosov z učitelji ni prišlo, $95 \%$ IZ [-0,06, 0,04].

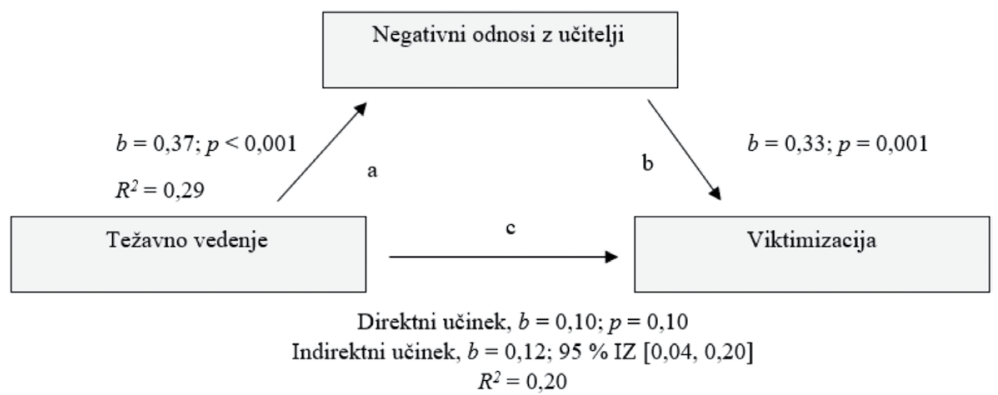

Slika 2: Mediatorski odnos med težavnim vedenjem in viktimizacijo ter negativnimi odnosi z učitelji kot mediatorjem odnosa.

Iz Slike 2 je razvidno, da je težavno vedenje pozitiven napovednik negativnih odnosov z učitelji (pot a), negativni odnosi z učitelji pa so pozitiven napovednik viktimizacije (pot b). Interval zaupanja (95\% IZ $[0,04,0,20])$ kaže, da je prišlo do mediatorskega učinka negativnih odnosov $\mathrm{z}$ učitelji na povezavo med težavnim vedenjem in viktimizacijo. Ob vključitvi negativnih odnosov z učitelji v model se je pokazalo, da težavno vedenje ni več pomemben napovednik viktimizacije (pot c), 
čeprav težavno vedenje brez vključenih negativnih odnosov z učitelji pozitivno napoveduje viktimizacijo $(b=0,22 ; p<0,00 \mathrm{I})$.

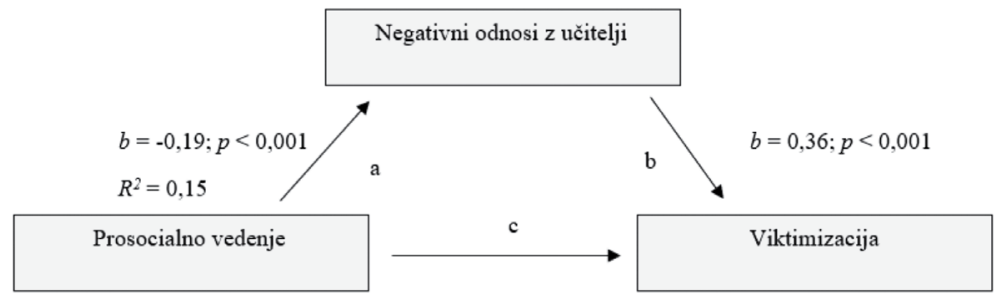

Direktni učinek, $b=-0,05 ; p=0,25$

Indirektni učinek, $b=-0,07 ; 95 \%$ IZ $[-0,12,-0,02]$

$$
R^{2}=0,19
$$

Slika 3: Mediatorski odnos med prosocialnim vedenjem in viktimizacijo ter negativnimi odnosi z učitelji kot mediatorjem odnosa.

Prosocialno vedenje je negativen napovednik negativnih odnosov z učitelji (pot a) in pojasni is \% variance (Slika 6). Ob vključitvi negativnih odnosov z učitelji v model lahko ugotovimo, da je prišlo do mediatorskega učinka negativnih odnosov z učitelji ( $95 \% \operatorname{IZ~}[-0,12,-0,02])$, in sicer se je ob vključitvi mediatorske spremenljivke zgodilo, da prosocialno vedenje ni več napovednik viktimizacije (pot c), saj je bilo prosocialno vedenje brez vključitve negativnih odnosov $\mathrm{z}$ učitelji statistično značilen negativni napovednik viktimizacije ( $b=-0,11 ; p=0,005)$.

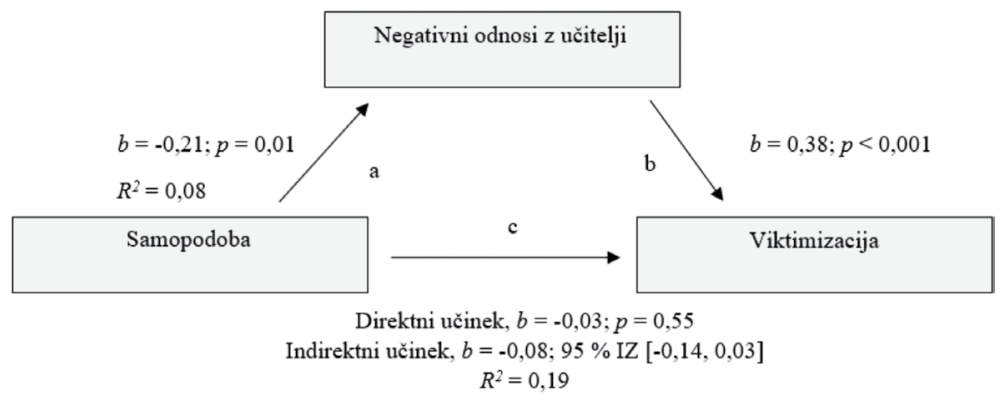

Slika 4: Mediatorski odnos med samopodobo in viktimizacijo ter negativnimi odnosi z učitelji kot mediatorjem odnosa.

Slika 4 kaže, da je samopodoba statistično značilen negativni napovednik negativnih odnosov $\mathrm{z}$ učitelji (pot a), ni pa značilen napovednik viktimizacije (pot c). V modelu prav tako ni prišlo do mediatorskega učinka negativnih odnosov z učitelji, $95 \%$ IZ [-0,1 4, 0,03]. 


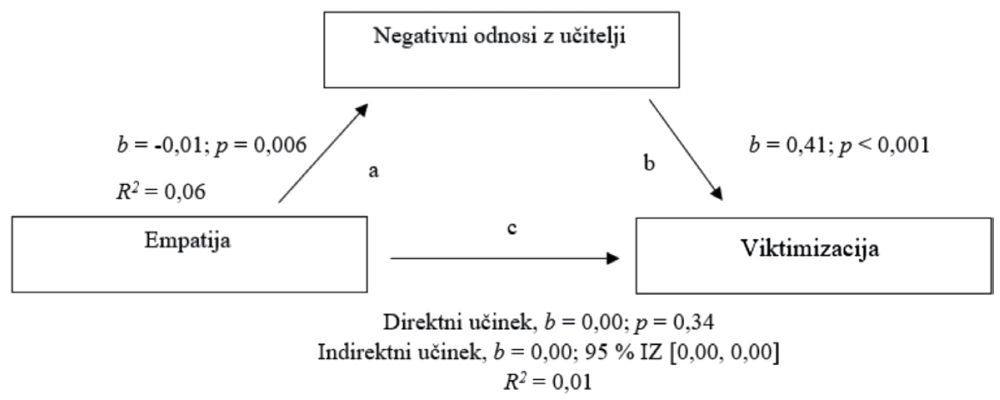

Slika s: Mediatorski odnos med empatijo in viktimizacijo ter negativnimi odnosi z učitelji kot mediatorjem odnosa.

Iz Slike 5 je razvidno, da je empatija statistično značilen napovednik negativnih odnosov z učitelji (pot a), vendar ni pomemben napovednik viktimizacije (pot c). $\mathrm{V}$ modelu ni prišlo do mediatorskega učinka negativnih odnosov z učitelji, $95 \%$ IZ [0,00, 0,00].

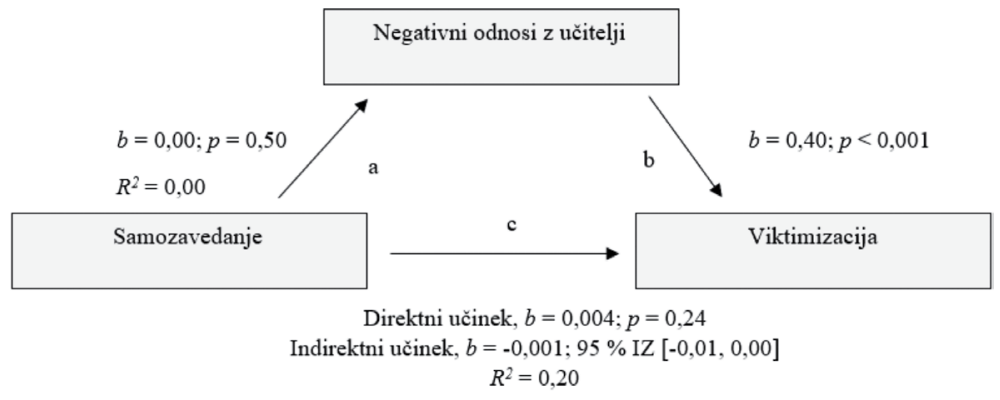

Slika 6: Mediatorski odnos med samozavedanjem in viktimizacijo ter negativnimi odnosi z učitelji kot mediatorjem odnosa.

Slika 6 kaže, da samozavedanje ni napovednik ne negativnih odnosov z učitelji (pot a) in ne viktimizacije (pot c). Iz rezultatov je mogoče sklepati, da negativni odnosi z učitelji ne predstavljajo mediatorja povezave med samozavedanjem in viktimizacijo, $95 \%$ IZ [-o, OI, 0,00].

\section{Razprava}

Namen razprave je bil preveriti napovedno vrednost različnih dejavnikov viktimizacije, pri čemer so naju zanimali dejavniki na ravni odnosov $\mathrm{z}$ vrstniki (pozitivni odnosi z vrstniki, težavno vedenje in prosocialno vedenje), dejavniki na ravni odnosov $z$ učitelji (pozitivni in negativni odnosi z učitelji) in dejavniki na ravni posameznika - čustvene in socialne 
kompetence (samopodoba, empatija, samozavedanje). Dodatno naju je zanimala tudi mediatorska vloga negativnih odnosov med učenci in učitelji v odnosu med preverjanimi psihosocialnimi značilnostmi in viktimizacijo. Ti odgovori služijo kot osnova vpeljavi smernic na sistemski ravni.

Dejavniki na ravni odnosov z vrstniki (pozitivni odnosi z vrstni$\mathrm{ki}$, težavno vedenje, prosocialno vedenje) so skladno s pričakovanji pojasnili najvišji odstotek variance viktimizacije, pri čemer se je pokazalo, da imajo izmed preverjanih spremenljivk najpomembnejšo vlogo pozitivni odnosi z vrstniki, ki so negativen napovednik viktimizacije. Torej, boljši, kot bodo zaznani odnosi z ostalimi vrstniki (npr. socialna opora s strani vrstnikov, socialna sprejetost), nižja bo poročana stopnja viktimizacije učencev. Podobno je bilo ugotovljeno tudi v drugih raziskavah (npr. Holt in Espelage, 2007; Sentse, Kretschmer in Salmivalli, 2015), kar kaže, da pozitivni odnosi z vrstniki učence varujejo pred pojavom viktimizacije. Prosocialno vedenje $\mathrm{v}$ tem modelu ni napovednik viktimizacije, kar je skladno tudi s predhodnimi ugotovitvami (Coleman in Byrd, 2003). Pri tem je treba opozoriti, da so rezultati vzdolžne študije pokazali, da so odnosno viktimizirani učenci, za katere je bila značilna visoka stopnja prosocialnega vedenja, po enem letu poročali o nižji stopnji osamljenosti kot tiste žrtve z nižjo stopnjo prosocialnega vedenja (Griese in Buhs, 20I4). To kaže na to, da lahko spodbujanje prosocialnega vedenja pri žrtvah pomaga $\mathrm{k}$ zmanjševanju dolgoročnih posledic viktimizacije. Težavno vedenje prav tako ni napovednik viktimizacije $\mathrm{v}$ tem modelu, kar je v neskladju z rezultati predhodnih raziskav (Gini, 2008; Marengo et al., 20I8). Pri tem je treba opozoriti, da je težavno vedenje bilo napovednik viktimizacije, dokler niso bili v model vključeni odnosi z učitelji.

Presenetljivo in v neskladju s pričakovanji so rezultati ob vključitvi odnosov med učenci in učitelji v model pokazali, da so tako pozitivni kot negativni odnosi z učitelji pozitiven napovednik viktimizacije, vendar se je ob vključitvi čustvenih in socialnih kompetenc pokazalo, da ostajajo statistično značilen napovednik viktimizacije zgolj negativni odnosi med učenci in učitelji. Podobno je bilo ugotovljeno tudi v predhodnih raziskavah, in sicer se je pokazalo, da negativni odnosi z učitelji v večji meri napovedujejo viktimizacijo kot pozitivni odnosi z učitelji (TroopGordon in Kopp, 20II). Glede pozitivnih odnosov je treba dodati, da dolgoročno pozitivni odnosi med učenci in učitelji ne varujejo učencev pred pojavom viktimizacije (Troop-Gordon in Kopp, 20II). Temu je treba dodati, da vloga kakovostnih odnosov med učenci in učitelji še vedno ostaja nejasna, saj večina študij (npr. Elledge et al., 20ı6; Serdiouk, Berry in Gest, 2016) kaže na pomemben vpliv pozitivnih odnosov z učitelji na pojavnost viktimizacije predvsem takrat, ko učenec nima kakovostnih 
odnosov z vrstniki. Pozitivni odnosi z učitelji so lahko pozitiven napovednik viktimizacije v primeru, ko drugi učenci te odnose označujejo negativno, kar lahko spodbudi zbadanje učencev, ki se z učitelji dobro razumejo. Negativni odnosi z učitelji so se pokazali kot izjemno pomemben napovednik viktimizacije, in sicer slabši, kot so zaznani odnosi z učitelji, višja je poročana stopnja viktimizacije, kar je skladno z rezultati predhodnih raziskav, kjer je bilo prav tako ugotovljeno, da negativni odnosi $\mathrm{z}$ učitelji kažejo na večjo verjetnost, da so učenci deležni nasilja (LucasMolina et al., 20ı5; Marengo et al., 20ı8). Pri raziskovanju viktimizacije in odnosov z učitelji je bilo prav tako predpostavljeno, da za preprečevanje doživljanja nasilja pri učencih ni nujno, da imajo pozitivne odnose $\mathrm{z}$ učitelji, ampak je dovolj to, da so odnosi med njimi ustrezni in da jih učenci ne označujejo kot negativne (Sulkowski in Simmons, 2017), kar učiteljem omogoča, da vplivajo na razredno klimo, se učinkovito odzivajo na težave in pomagajo učencem, da se počutijo varne in sprejete, kar lahko pomaga pri zmanjševanju doživljanja nasilja med učenci (Jennings in Greenberg, 2009).

Čustvene in socialne kompetence sicer pojasnjujejo majhen delež variance viktimizacije, a nobena preučevana kompetenca (samopodoba, empatija in samozavedanje) na tem vzorcu ne napoveduje viktimizacije statistično pomembno. Samopodoba je bila v kontekstu viktimizacije ena izmed najbolj preučevanih lastnosti posameznika, saj si nasilneži za svoje žrtve izbirajo učence, ki so bolj negotovi vase in imajo nižjo samopodobo (Salmivalli et al., 1996), a vendar se na tem vzorcu samopodoba ni izkazala kot statistično značilna. Podobno kot samopodoba tudi empatija ne napoveduje viktimizacije, kar se sklada z rezultati raziskav, ki prav tako niso odkrile napovedne vrednosti empatije pri viktimiziranih učencih (Raskauskas, Gregory, Harvey, Rifshana in Evans, 20IO). Slednje kaže, da ima empatija učencev večjo vlogo pri izvajanju nasilja kot pri doživljanju. Pomemben napovednik viktimizacije prav tako ni bilo samozavedanje učencev, ki temelji na opisovanju in opazovanju občutkov, ki se jim porajajo. Raziskovanje tega vidika samozavedanja v povezavi z viktimizacijo se je pričelo nedavno (Riggs in Brown, 2017), vendar so rezultati v neskladju $z$ našimi ugotovitvami, saj so pokazali negativno povezavo med čuječnostjo kot vidikom samozavedanja in viktimizacijo.

Razumevanje vpliva odnosov med učenci in učitelji na odnos med preverjanimi psihosocialnimi značilnostmi učencev in viktimizacijo je še posebej pomembno iz vidika vloge učiteljev $\mathrm{v}$ procesu viktimizacije. Preverjali sva mediatorsko vlogo negativnih odnosov z učitelji in ugotovili, da ti mediirajo odnos med težavnim vedenjem in viktimizacijo 
ter prosocialnim vedenjem in viktimizacijo, vendar ne mediirajo odnosa med drugimi preučevanimi značilnostmi in viktimizacijo. Upoštevanje negativnih odnosov z učitelji pri odnosu med težavnim vedenjem in viktimizacijo kaže, da v kolikor so prisotni negativni odnosi z učitelji, težavno vedenje ni več pozitiven napovednik viktimizacije. Podobno vplivajo negativni odnosi z učitelji tudi na odnos med prosocialnim vedenjem in viktimizacijo, in sicer ob prisotnosti negativnih odnosov z učitelji prosocialno vedenje ne predstavlja več varovalnega dejavnika viktimizacije. Presenetljivo imajo lastnosti na ravni odnosov z učitelji vpliv na lastnosti na ravni posameznika v sklopu viktimizacije, saj naj bi prav slednje v največji meri napovedovale viktimizacijo. Tovrstne ugotovitve kažejo na velik vpliv negativnih odnosov z učitelji na pojavnost viktimizacije v razredu, podobno je bilo ugotovljeno tudi, da so učenci, ki poročajo o konfliktnih odnosih z učitelji, prav žrtve ali nasilneži-žrtve. Učenci imajo tudi večjo verjetnost, da postanejo žrtve, če imajo poleg težav z vrstniki še težave v odnosu z učitelji (Marengo et al., 2018).

\section{Zaključek}

Najine ugotovitve kažejo na velik vpliv pozitivnih odnosov z vrstniki in negativnih odnosov z učitelji na pojav viktimizacije. Ugotovili sva, da so pozitivni odnosi $z$ vrstniki negativen napovednik viktimizacije, in sicer boljše, kot učenci ocenjujejo svoje odnose z vrstniki, v manjši meri poročajo o viktimizaciji, in da so negativni odnosi z učitelji pozitiven napovednik viktimizacije. To pomeni, da bolj, kot učenci poročajo o negativnih odnosih z učitelji, o višji stopnji viktimizacije poročajo. Nadalje sva ugotovili, da negativni odnosi z učitelji vplivajo tudi na odnos med težavnim vedenjem in viktimizacijo ter prosocialnim vedenjem in viktimizacijo: $\mathrm{v}$ kolikor so negativni odnosi z učitelji prisotni, težavno vedenje ni več pozitiven napovednik viktimizacije, prosocialno vedenje pa ne več negativen napovednik viktimizacije. Prve predstavljene ugotovitve kažejo, da pozitivni odnosi z vrstniki v večji meri napovedujejo viktimizacijo kot kakovostni odnosi z učitelji (Elledge et al., 20I6), kljub temu pa negativni odnosi z učitelji kažejo velik vpliv na viktimizacijo. Ugotovitve torej kažejo na pomembnost spodbujanja pozitivnih odnosov $\mathrm{z}$ učitelji, in sicer v izogib negativnim odnosom, ki ob viktimizaciji vplivajo tudi na vrsto drugih neželenih pojavov v šolskem okolju.

Ugotovitve imajo poleg znanstvene tudi praktično vrednost. Kar zadeva pozitivne odnose $\mathrm{z}$ vrstniki, je zelo pomembno, da se za obstoječe žrtve ustvari podporna mreža tistih učencev, ki niso več žrtve, in tistih učencev, ki so opazovalci medvrstniškega nasilja, saj je bilo ugotovljeno, da žrtve, ki poiščejo oporo v času doživljanja nasilja, v primerjavi 
z drugimi žrtvami, ki tega ne storijo, prej prenehajo biti žrtve (Smith, Talamelli, Cowie, Naylor in Chauhan, 2004). Če v skladu s predhodnimi raziskavami (Fox in Boulton, 2005) predpostavimo tudi, da imajo žrtve nižje socialne spretnosti, je zanje nujen trening socialnih veščin za lažje vzpostavljanje ugodnih odnosov z vrstniki. Rezultati so prav tako pokazali, da je ob spodbujanju pozitivnih odnosov med učenci enako pomembna skrb učiteljev za razvoj podpornih in pozitivnih odnosov med njimi in učenci ter predvsem preventivne dejavnosti za izboljšanje negativnih odnosov med učitelji in učenci. Pri tem je pomembno sprejemanje odgovornosti za odnos, ki je vedno na strani odraslega (Jull in Jensen, 20I0), razvijanje učinkovitih načinov delovanja, odnosna kompetentnost ter razvijanje čustvenih in socialnih kompetenc učiteljev (Jennings in Greenberg, 2009), kar bi bilo smiselno vključiti tudi v izobraževanje prihodnjih učiteljev.

Rezultate najinega prispevka je treba povzemati s previdnostjo, saj je bil v raziskavi uporabljen majhen vzorec učencev, raziskava je bila zastavljena prečno, pokazala se je nižja zanesljivost dveh podlestvic iz Vprašalnika prednosti in slabosti, prav tako so bile uporabljene zgolj mere samoporočanja s strani učencev. Zaradi kompleksnosti preučevanega pojava in nezanesljivosti mer odnosov $\mathrm{z}$ učitelji bi bilo smiselno vključiti učitelje in vrstniško poročanje. Kljub navedenim pomanjkljivostim prispevek odstira do sedaj pretežno neraziskane vidike viktimizacije v slovenskem šolskem prostoru (vloga odnosov z učitelji ter čustvenih in socialnih kompetenc) in kaže na že velikokrat poudarjeno vlogo odnosov z vrstniki in učitelji.

$\mathrm{V}$ nadaljnje raziskovanje je smiselno vključiti še druge pomembne socialne in čustvene dejavnike na ravni učencev in učiteljev v kontekstu viktimizacije, predvsem se je treba raziskovanja tega pojava lotiti preko vzdolžnega raziskovalnega načrta in kljub temu da viktimizacija ni neposredno povezana $z$ izvajanjem nasilja, raziskati še ta vidik zaradi lažjega načrtovanja intervencij. Smiselno bi bilo nadalje raziskati učinkovitost posameznih intervencij na zmanjševanje viktimizacije, predvsem z vidika čustvenih in socialnih kompetenc (tudi učiteljev), ki se sicer v tem prispevku niso pokazale kot napovedniki viktimizacije, a vendar lahko znotraj strategij čustvenega in socialnega učenja najdemo veliko tehnik, ki vplivajo na izboljšanje psihičnega blagostanja učencev in odnosov med učenci.

\section{Literatura}

Baer, R., Smith, G. T., in Allen, K. B. (2004) Assessment of mindfulness by self-report, Assessment II, str. 191-206. doi:10.1016/j.copsyc.2018.10.015 
Belmont, M., Skinner, E., Wellborn, J., in Connell, J. (1992) Teacher as social context (TASC), Student report measures of teacher provision of involvement, structure, and autonomy support (Technical Report). Rochester, NY: University of Rochester.

Bollmer, J. M., Milich, R., Harris, M. J., in Maras, M. A. (2005) A friend in need: The role of friendship quality as a protective factor in peer victimization and bullying, Journal of Interpersonal Violence 20(6), str. 70I712. doi:10.1177/0886260504272897

Brown, K. W., in Ryan, R. M. (2003) The Benefits of Being Present: Mindfulness and Its Role in Psychological Well-Being, Journal of Personality and Social Psychology 84(4), str. 822-848. doi:10.1037/0022-3514. 84.4 .822

Caravita, S. C. S., Di Blasio, P., in Salmivalli, C. (2009) Unique and inter_ active effects of empathy and social status on involvement in bullying, Social Development I8(I), str. I40-163. doi:I0.IIII/j.I4679507.2008.00465.x

Card, N. A., in Hodges, E. V. E. (2008) Peer Victimization Among Schoolchildren: Correlations, Causes, Consequences, and Considerations in Assessment and Intervention, School Psychology Quarterly 23(4), str. 45I-46I. doi:10.1037/a0012769

Coleman, P. K., in Byrd, C. P. (2003) Interpersonal Correlates of Peer Victimization among Young Adolescents, Journal of Youth and Adolescence 32(4), str. 301-314. doi:10.1023/A:I023089028374

Davis, M. H. (1980) A Multidimensional Approach to Individual Differences in Empathy, JSAS Catalog of Selected Documents in Psychology 10, 85. doi:10.1037/0022-3514.44.1.113

Davis, M. H. (1983) Measuring Individual Differences in Empathy: Evidence for a Multidimensional Approach, Journal of Personality and Social Psychology 44(I), str. I13-126. doi:10.1037/0022-3514.44.I.113

Davis, M. H. (1996) Empathy. New York, NY: Routledge. doi:10.4324/9780429493898

Di Stasio, M. R., Savage, R., in Burgos, G. (2016). Social comparison, competition and teacher-student relationships in junior high school classrooms predicts bullying and victimization, Journal of Adolescence 53, str. 207-216. doi:10.1016/j.adolescence.2016.10.002

Du, C., DeGuisto, K., Albright, J., in Alrehaili, S. (2018) Peer Support as a Mediator between Bullying Victimization and Depression, International Journal of Psychological Studies Io(I), str. 59-68. doi:I0.5539/ijps.vionip59 
Durlak, J. A., Dymnicki, A. B., Taylor, R. D., Weissberg, R. P., in Schellinger, K. B. (20II) The Impact of Enhancing Students' Social and Emotional Learning: A Meta-Analysis of School-Based Universal Interventions, Child Development 82(I), str. 405-432. doi:10.1007/ sio972-0I4-938I-4

Eisenberg, N., Fabes, R. A., in Spinrad, T. L. (2006) Prosocial development. V: N. Eisenberg, W. Damon in R. M. Lerner [ur.] Handbook of child psychology: Social, emotional, and personality development, Vol. 3. (str. 646-718). New York, NY: John Wiley \& Sons Inc.

Elledge, L. C., Elledge, A. R., Newgent, R. A., in Cavell, T. A. (2016) Social Risk and Peer Victimization in Elementary School Children: The Protective Role of Teacher-Student Relationships, Journal of Abnormal Child Psychology 44(4), str. 691-703. doi:10.1007/s10802-015-0074-Z

Fanti, K. A., in Henrich, C. C. (2015) Effects of Self-Esteem and Narcissism on Bullying and Victimization During Early Adolescence, Journal of Early Adolescence 35(I), str. 5-29. doi:10.1177/0272431613519498

Fox, C. L., in Boulton, M. J. (2005) The social skills problems of victims of bullying: Self, peer and teacher perceptions, British Journal of Educational Psychology, 75(2), str. 313-328. doi:10.1348/000709905X25517

Gini, G. (2008) Associations between bullying behaviour, psychosomatic complaints, emotional and behavioural problems, Journal of Paediatrics and Child Health 44(9), str. 492-497. doi:IO.IIII/j.I440-I754.2007.01155.x

Goodman, R. (1997) The Strengths and Difficulties Questionnaire: A research note, Journal of Child Psychology and Psychiatry 38(5), str. 58I-586. doi:IO.IIII/cge.12538

Goodman, R. (200I) Psychometric properties of the strengths and difficulties questionnaire, Journal of the American Academy of Child and Adolescent Psychiatry, 40(II), str. 1337-1345. doi:10.1097/00004583-200111000-00015

Griese, E. R., in Buhs, E. S. (2014) Prosocial Behavior as a Protective Factor for Children's Peer Victimization, Journal of Youth and Adolescence, 43(7), str. 1052-1065. doi:10.1007/s10964-013-0046-y

Griese, E. R., Buhs, E. S., in Lester, H. F. (2016) Peer victimization and prosocial behavior trajectories: Exploring sources of resilience for victims, Journal of Applied Developmental Psychology 44, str. I-II. doi:10.1016/j. appdev.2016.01.009

Guérin, F., Marsh, H. W., in Famose, J. P. (2003) Construct validation of the self-description questionnaire ii with a French sample, 
European Journal of Psychological Assessment 19(2), str. 142-150. doi:10.1027//1015-5759.19.2.142

Hamre, B. K., in Pianta, R. C. (2005) Can Instructional and Emotional Support in the First-Grade Classroom Make a Difference for Children at Risk of School Failure? Child Development 76(5), str. 949-967. doi:10.1097/00006454-198607000-00035

Hawker, D., in Boulton, M. (2000) Twenty years research on peer victimisation and psycho-social maladjustment, Journal of Child Psychology and Psychiatry 4I(4), str. 44I-455. doi: I0.IIII/I469-7610.00629

Hodges, E. V. E., in Perry, D. G. (1999) Personal and interpersonal antecedents and consequences of victimization by peers, Journal of Personality and Social Psychology 76(4), str. 677-685. doi:10.1037/0022-3514.76.4.677

Holt, M. K., in Espelage, D. L. (2007) Perceived social support among bullies, victims, and bully-victims, Journal of Youth and Adolescence 36(8), str. 984-994. doi:10.1007/sio964-006-9153-3

Huang, F. L., Lewis, C., Cohen, D. R., Prewett, S., in Herman, K. (2018) Bullying involvement, teacher-student relationships, and psychosocial outcomes, School Psychology Quarterly 33(2), str. 223-234. doi:10.1037/ spq0000249

Hymel, S., in Swearer, S. M. (2015) Four decades of research on school bullying: An introduction, American Psychologist 70(4), str. 293-299. doi:10.1037/a0038928

Isaacs, J., Hodges, E. V. E., in Salmivalli, C. (2008) Long-term consequences of victimization by peers: A follow-up from adolescence to young adulthood, International Journal of Developmental Sciences 2(4), str. 387-397. doi:10.3233/DEV-2008-2404

Jenkins, L. N., Demaray, M. K., Fredrick, S. S., in Summers, K. H. (2016) Associations Among Middle School Students' Bullying Roles and Social Skills, Journal of School Violence 15(3), str. 259-278. doi:10.1080/I 5388220.2014 .986675

Jennings, P. A., in Greenberg, M. T. (2009) The Prosocial Classroom: Teacher Social and Emotional Competence in Relation to Student and Classroom Outcomes, Review of Educational Research 79(I), str. 49I525. doi:10.3102/0034654308325693

Juul, J., in Jensen, H. (2010) Od poslušnosti do odgovornosti. Radovljica: Didakta.

Juvonen, J., in Graham, S. (2014) Bullying in Schools: The Power of Bullies and the Plight of Victims, Annual Review of Psychology 65, str. 159-185. doi:IO.II46/annurev-psych-OIO2I3-II5O3O 
Kokkinos, C. M., in Kipritsi, E. (2012) The relationship between bullying, victimization, trait emotional intelligence, self-efficacy and empathy among preadolescents, Social Psychology of Education I5(I), str. 4I-58. doi:10.1007/SII218-011-9168-9

Košir, K., Pivec, T., Klasinc, L., Špes, T., in Horvat, M. (2018) Psihosocialne značilnosti učencev kot napovedniki različnih oblik medvrstniške viktimizacije in nasilnega vedenja, Psihološka Obzorja/Horizons of Psychology 186, str. 171-186. doi:10.20419/2018.27.494

Kozina, A., Vidmar, M., Saelzer, C., Rasmunson, M., Marušić, I., Jensen, H., Lund Nielsen, B., Vieluf, S., Ojsteršek, A., in Jurko, S. (2017) Hand in Hand: Social and Emotional Skills for Tolerant and Non-discriminative Societies (A Whole School Approach), Erasmus $K_{3}$ project. Pridobljeno s http://handinhand.si

LaFontana, K. M., in Cillessen, A. H. N. (2010) Developmental changes in the priority of perceived status in childhood and adolescence, Social Development I9(I), str. I30-I 47. doi:I0.IIII/j.I467-9507.2008.00522.x

Lenzi, M., Furlong, M. J., Dowdy, E., Sharkey, J., Gini, G., in Altoè, G. (2015) The quantity and variety across domains of psychological and social assets associated with school victimization, Psychology of Violence 5(4), str. 4II-42I. doi:10.1037/a0039696

Lucas-Molina, B., Williamson, A. A., Pulido, R., in Perez-Albeniz, A. (2015) Effects of Teacher-Student Relationships on Peer Harrassment: A Multilevel Study, Psychology in Schools 52(3), str. 298-314. doi:10.1002/ pits.21822

Malecki, C. K., Demaray, M. K., Coyle, S., Geosling, R., Rueger, S. Y., in Becker, L. D. (2015) Frequency, power differential, and intentionality and the relationship to anxiety, depression, and self-esteem for victims of bullying, Child \& Youth Care Forum 44(I), str. II5-I3I. doi: I0.1007/ sios66-0i4-9273-y

Marengo, D., Jungert, T., Iotti, N. O., Settanni, M., Thornberg, R., in Longobardi, C. (2018) Conflictual student-teacher relationship, emotional and behavioral problems, prosocial behavior, and their associations with bullies, victims, and bullies/victims, Educational Psychology 38(9), str. I20I-1217. doi:10.1080/01443410.2018.1481199

Marsh, H. W. (1992) SelfDescription Questionnaire (SDQ) II: A theoretical and empirical basis for the measurement of multiple dimensions of adolescent self-concept: An interim test manual and a research monograph. Novi Južni Wales, Avstralija: University of Western Sydney, Faculty of Education. 
O'Moore, M., in Kirkham, C. (2002) Self-esteem and its relationship to bullying behaviour, Aggressive Behavior 27(4), str. 269-283. doi:10.1002/ ab.ıoro

OECD (2017) PISA 2015 Technical Report. Pridobljeno I0. 4. 2019 s: http:// www.oecd.org/pisa/data/2015-technical-report/

Olweus, D. (1997) Bully/victim problems in school: Facts and intervention, European Journal Of Psychology Of Education I2(4), str. 495-510.

Racz, S. J., in McMahon, R. J. (20II) The Relationship Between Parental Knowledge and Monitoring and Child and Adolescent Conduct Problems: A ro-Year Update, Clinical Child and Family Psychology Review I 4(4), str. 377-398. doi:10.1007/s10567-011-0099-y

Raskauskas, J. L., Gregory, J., Harvey, S. T., Rifshana, F., in Evans, I. M. (20I0) Bullying among primary school children in New Zealand: Relationships with prosocial behaviour and classroom climate, Educational Research 52(I), str. I-I3. doi:10.1080/00131881003588097

Raskauskas, J., Rubiano, S., Offen, I., in Wayland, A. K. (2015) Do social self-efficacy and self-esteem moderate the relationship between peer victimization and academic performance? Social Psychology of Education 18(2), str. 297-314. doi:10.1007/s11218-015-9292-Z

Riggs, N. R., in Brown, S. M. (2017) Prospective Associations Between Peer Victimization and Dispositional Mindfulness in Early Adolescence, Prevention Science I8(4), str. 48I-489. doi:10.1007/sIII2I-0I7-0750-Z

Sainio, M., Veenstra, R., Huitsing, G., in Salmivalli, C. (2011) Victims and their defenders: A dyadic approach, International Journal of Behavioral Development 35(2), str. 144-151. doi:10.1177/0165025410378068

Salmivalli, C., Lagerspetz, K., Bjorkqvist, K., in Osterman, K. (1996) Bullying as a Group Process: Participant Roles and Their Relations to Social Status Within the Group, Agressive Behavior 22, str. I-I5.

Salmivalli, C., in Peets, K. (2009) Bullies, victims, and bully-victim relationships in middle childhood and early adolescence. V: K. H. Rubin, W. M. Bukowski in B. Lauren [ur.], Handbook of peer interactions, relationships, and groups (str. 322-340). New York, NY, ZDA: The Guilford Press. doi:10.5860/choice.46-649I

Schwartz, D., McFadyen-Ketchum, S. A., Dodge, K. A., Pettit, G. S., in Bates, J. E. (1998) Peer group victimization as a predictor of children's behavior problems at home and in school, Development and Psychopathology Io(I), str. 87-99. doi:I0.IOI7/So9545794980013IX

Sentse, M., Dijkstra, J. K., Salmivalli, C., in Cillessen, A. H. N. (2013) The Dynamics of Friendships and Victimization in Adolescence: A 
Longitudinal Social Network Perspective, Aggressive Behavior 39(3), str. 229-238. doi:10.1002/ab.21 469

Sentse, M., Kretschmer, T., in Salmivalli, C. (2015) The Longitudinal Interplay between Bullying, Victimization, and Social Status: Agerelated and Gender Differences, Social Development 24(3), str. 659677. doi:I0.1111/sode.12115

Serdiouk, M., Berry, D., in Gest, S. D. (2016) Teacher-child relationships and friendships and peer victimization across the school year, Journal of Applied Developmental Psychology 46, str. 63-72. doi:10.1016/j. appdev.2016.08.001

Smith, P. K., Talamelli, L., Cowie, H., Naylor, P., in Chauhan, P. (2004) Profiles of non-victims, escaped victims, continuing victims and new victims of school bullying, British Journal of Educational Psychology 73(4), str. 565-581. doi:10.1348/0007099042376427

Solberg, M. E., in Olweus, D. (2003) Prevalence Estimation of School Bullying with the Olweus Bully/Victim Questionnaire, Aggressive Behavior 29(3), str. 239-268. doi: 10.1002/ab.10047

Spence, S. H., de Young, A., Toon, C., in Bond, S. (2009) Longitudinal examination of the associations between emotional dysregulation, coping responses to peer provocation, and victimisation in children, Australian Journal of Psychology 6I(3), str. 145-155. doi:10.1080/00049530802259076

Sulkowski, M. L., in Simmons, J. (2017) The protective role of teacher-student relationships against peer victimization and psychosocial distress, Psychology in the Schools 55(2), str. 137-150. doi:10.1002/pits.22086

Thornberg, R., Wänström, L., in Pozzoli, T. (2017) Peer victimisation and its relation to class relational climate and class moral disengagement among school children, Educational Psychology 37(5), str. 524-536. doi: I0.1080/01443410.2016.1150423

Troop-Gordon, W., in Kopp, J. (2011) Teacher-child relationship quality and children's peer victimization and aggressive behavior in late childhood, Social Development 20(3), str. 536-56I. doi:I0.IIII/j.I 467-9507.2011.00604.x

Troop-Gordon, W., in Ladd, G. W. (2015) Teachers' Victimization-Related Beliefs and Strategies: Associations with Students' Aggressive Behavior and Peer Victimization, Journal of Abnormal Child Psychology 43(I), str. 45-60. doi:10.1007/sio802-013-9840-y

van Noorden, T. H. J., Haselager, G. J. T., Cillessen, A. H. N., in Bukowski, W. M. (2015) Empathy and Involvement in Bullying in Children and 
Adolescents: A Systematic Review, Journal of Youth and Adolescence 44(3), str. 637-657. doi:10.1007/sio964-014-0135-6

Waasdorp, T. E., Pas, E. T., O’Brennan, L. M., in Bradshaw, C. P. (2or I) A Multilevel Perspective on the Climate of Bullying: Discrepancies Among Students, School Staff, and Parents, Journal of School Violence IO(2), str. II5-I32. doi:10.1080/15388220.2010.539164.

Wang, F., Leary, K. A., Taylor, L. C., in Derosier, M. E. (2016) Peer and Teacher Preference, Student-Teacher Relationships, Student Ethnicity, and Peer Victimization in Elementary School, Psychology in Schools 53(5), str. 488-501. doi:10.1002/pits.21922

Weissberg, R. P., Durlak, J. A., Domitrovich, C. E., in Gullotta, T. P. (2015) Social and emotional learning: Past, present, and future. V: J. A. Durlak, C. E. Domitrovich, R. P. Weissberg in T. P. Gullotta [ur.], Handbook of social and emotional learning: Research and practice (str. 3-19). New York, NY, ZDA: The Guilford Press.

Yang, A., Li, X., in Salmivalli, C. (2016) Maladjustment of bully-victims: validation with three identification methods, International Journal of Experimental Educational Psychology 36(8), str. 1390-I 407. doi:10.1080 /OI443410.2015.1015492

Zych, I., Ttofi, M. M., in Farrington, D. P. (2019) Empathy and CallousUnemotional Traits in Different Bullying Roles: A Systematic Review and Meta-Analysis, Trauma, Violence, and Abuse 20(I), str. 3-21. doi:10.1177/1524838016683456 